\title{
BIOCHEMICAL CHANGES ASSOCIATED TO SOYBEAN SEEDS OSMOCONDITIONING DURING STORAGE ${ }^{1}$
}

\author{
ALESSANDRO DE LUCCA E BRACCINI², MÚCIO SILVA REIS ${ }^{3}$, MAURÍLIO ALVES MOREIRA4 \\ CARLOS SIGUEYUKI SEDIYAMA ${ }^{5}$ and CARLOS ALBERTO SCAPIM ${ }^{2}$
}

\begin{abstract}
A work was carried out with the purpose of verifying the biochemical changes associated to soybean (Glycine max (L.) Merrill) seeds osmoconditioning. Seeds of the UFV 10, IAC 8 and Doko RC cultivars harvested at R8 development stage and submitted to different treatments were used. The biochemical evaluations were performed during seed storage, after the hydration-dehydration process. Initially, seeds were osmoconditioned in a polyethylene glycol (PEG 6000) solution, with the osmotic potential of $-0.8 \mathrm{MPa}$ and $20^{\circ} \mathrm{C}$, for a period of four days. After that, seeds were dried back until the initial moisture content (10-11\%) and stored in natural conditions for three and six months. Two controls were used: untreated seeds (dry seeds) and water soaked seeds. Seed changes in protein and lipid, hexanal accumulation and fatty acids contents were evaluated. The results showed that seed storage under laboratory natural conditions caused reduction in protein, lipid and polyunsaturated fatty acids content and promoted hexanal production. Storage periods reduced protein levels for all treatments, however the PEG 6000 treatment showed lower protein reduction. The soybean seed storage increased hexanal production, but hexanal levels were smaller with osmoconditioning comparing to the other imbibition treatments.
\end{abstract}

Index terms: polyethylene glicol, protein, lipid, hexanal.

\section{ALTERAÇÕES BIOQUÍMICAS ASSOCIADAS AO CONDICIONAMENTO OSMÓTICO DE SEMENTES DE SOJA DURANTE O ARMAZENAMENTO}

RESUMO - Foi conduzido um trabalho com o objetivo de avaliar as alterações bioquímicas associadas ao condicionamento osmótico das sementes de soja (Glycine max (L.) Merrill). Foram utilizadas amostras de sementes das cultivares UFV 10, IAC 8 e Doko RC, colhidas no estádio R8 e submetidas a diferentes tratamentos de embebição. As avaliações bioquímicas foram realizadas no decorrer do armazenamento das sementes, após estas serem submetidas ao processo de hidratação-desidratação. Inicialmente, as sementes de soja foram submetidas ao tratamento de condicionamento osmótico em solução de polietileno glicol (PEG 6000), com potencial osmótico de -0,8 MPa, a uma temperatura de $20^{\circ} \mathrm{C}$, por quatro dias. Posteriormente, as sementes osmocondicionadas foram novamente desidratadas, até atingirem o conteúdo de umidade inicial (10 a 11\%), e armazenadas em condições normais do ambiente de laboratório, pelos períodos de três e seis meses. As sementes submetidas ao processo de hidratação-desidratação foram comparadas com duas testemunhas: sementes não-tratadas (secas) e sementes embebidas em água. Após cada período de armazenamento, as sementes foram avaliadas quanto às modificações nos teores de proteínas, lipídios, hexanal e ácidos graxos. Os resultados obtidos permitiram concluir que o armazenamento das sementes sob condições naturais de laboratório causou decréscimos nos teores de proteínas, lipídios e ácidos graxos poliinsaturados e promoveu aumento de hexanal. Os períodos de armazenamento reduziram os níveis de proteínas em todos os tratamentos; contudo, o tratamento das sementes com PEG 6000 foi o que apresentou os menores decréscimos nos seus teores. $\mathrm{O}$ armazenamento das sementes aumentou a produção de hexanal, porém os níveis foram menores com o condicionamento osmótico, em comparação com os demais tratamentos.

Termos para indexação: polietileno glicol, proteínas, lipídios, hexanal.

\footnotetext{
${ }^{1}$ Accepted for publication on April 16, 1999.

${ }^{2}$ Agronomist, D.Sc., Dep. de Agronomia, Universidade Estadual de Maringá, Av. Colombo, 5790 CEP 87020-900 Maringá, PR, Brazil. CNPq Scholar. E-mail: braccini@cca.uem.br
}

\footnotetext{
${ }^{3}$ Agronomist, D.Sc., Dep. de Fitotecnia, Universidade Federal de Viçosa (UFV), CEP 36571-000 Viçosa, MG, Brazil.

${ }^{5}$ Agronomist, Ph.D., Dep. de Bioquímica e Biologia Molecular, UFV.

${ }^{5}$ Agronomist, Ph.D., Dep. de Fitotecnia, UFV.
} 


\section{INTRODUCTION}

Soybean is considered the most important cultivated oil crop, comprising about $51 \%$ of the world production of vegetable oil. Also, because of its high protein content it has many commercial applications and soybean processing formed a large agro-industrial complex.

There has been an increasing demand for soybean seeds to satisfy the demands of an expanding producer and consumer market with very promising future perspectives. However, besides quantity, the quality of the seeds produced must be considered. The use of high quality seeds is essential to establish a suitable population in a soybean field, giving better financial results (Krzyzanowski et al., 1993).

Highly vigorous seeds germinate rapidly and uniformly, and are able to withstand environmental adversity, after sowing (Del Giúdice, 1996). However, the use of soybean seeds of low physiological quality is a common practice under our tropical and subtropical production conditions, leading to inadequate plant population in the field.

Various studies have been carried out to reduce the period between sowing and seedling emergence, as well as to increase seed tolerance to adverse environmental conditions during the germination phase. One of the most important developments in this area has been the seed osmotic conditioning technique, also referred in the literature as priming or osmoconditioning (Heydecker et al., 1973, 1975).

This technique has presented promising, and even surprising results, for seeds of legumes and forest species (Bradford, 1986). The few studies on soybean are encouraging, but more information is required before its use as a routine practice in seed technology (Knypl \& Khan, 1981).

Osmotic conditioning aims to reduce the time of seedling emergence, as well as synchronize and improve the germination percentage, by submitting the seeds to a certain period of imbibition using osmotic solutions. The seeds normally begin water uptake on contact with this solution, and stop the process as soon as they become balanced with the water potential of the solution. This potential should be adjusted to allow all the biochemical and physiological germination processes to take place, but to inhibit the cellular development and consequently root emergence, even after weeks of contact between the seed and the osmotic solution (Khan, 1992).

When the treatment conditions are favorable, the reserve mobilization, activation and re-synthesis of some enzymes, DNA and RNA synthesis start during osmotic conditioning. Rapid embryo growth results when the obstacle to germination is removed (Khan, 1992). Several physiological and biochemical changes take place in seeds during the priming treatment or as a consequence of the osmotic conditioning. These changes include macromolecular synthesis, several enzyme activities, increase in germinating power and vigor and overcoming of dormancy (Fu et al., 1988; Khan, 1992; Smith \& Coob, 1992; Sung \& Chang, 1993).

Recent studies have shown that osmotic conditioning in sweet pepper and tomato seeds is associated with DNA synthesis (Lantieri et al., 1994). Dell'Aquila \& Tritto (1991) observed that osmotic conditioning decreased the mean germination time in aged wheat seeds, and this was correlated with the restart of cellular division, seedling elongation, incorporation of ${ }^{3} \mathrm{H}$-thymidine in the DNA and with incorporation of ${ }^{3} \mathrm{H}$-leucine in proteins.

Bray et al. (1989) found detectable levels of ${ }^{3} \mathrm{H}$-thymidine incorporation in the DNA of leek seeds, during osmotic conditioning without cellular division. They also found that great increases in DNA synthesis in osmoconditioned leek seeds only happened after a period of relatively low synthesis activity of about six to nine hours.

Biochemical studies of Khan (1992) indicated that RNA metabolism and protein and enzyme synthesis were increased by osmotic conditioning, suggesting that this treatment makes precursors used for macromolecular synthesis available to the seeds. RNA, proteins and enzyme synthesis may occur due to the removal of certain inhibiting factors, such as abscisic acid (ABA) or to the production of promotor factors. Fu et al. (1988) and Bray et al. (1989) found out that great quantities of RNA were synthesized during or immediately after osmotic conditioning in peanut and leek seeds.

Khan (1992) found out that more amino acids were incorporated into proteins in osmoconditioned sweet 
pepper seeds during the first 24 hours, compared with seeds imbibed in water. In another study with seeds from the same species, Smith \& Coob (1992) found out that protein synthesis increases throughout the osmotic conditioning treatment.

Increases in enzymatic and metabolic activities are common characteristics during osmotic conditioning and seem to be related to the revigoration of the seeds during the subsequent germination. Alterations in the activities of certain enzymes, such as esterase, phosphatase acid and 3-phosphoglyceraldehyde dehydrogenase, suggest that the mobilization of reserve materials stored in the seeds such as carbohydrates, lipids and proteins may explain the increase in the germination and vigor induced by osmotic conditioning (Khan, 1992).

Increases in respiratory activities and in adenosine triphosphate (ATP) formation, necessary for macromolecular membrane and cell wall synthesis have been observed during or after osmotic conditioning. Fu et al. (1988) found that isocitrate lyase, ATPase and phosphatase acid activities were greater in conditioned pea seeds than in non-treated seeds. Smith \& Coob (1992) reported that the soluble protein content, aldolase and isocitrate enzyme activities increased significantly in sweet pepper seeds during osmotic conditioning.

Osmoconditioned seeds may be dried back to their initial moisture content and stored for variable periods of time depending on the species. Osmotically conditioned and dried seeds normally have a more rapid and uniform germination when subsequently re-hydrated, especially under adverse environmental conditions (Bradford, 1986). The mechanism of seed drying after osmotic conditioning is known as the hydration-dehydration process or dry back and is used to reduce the degree of moisture in seeds to levels compatible with storage and maintaining the beneficial effects of the treatment, without quality loss caused by rapid seed deterioration.

The few studies available using the osmotic conditioning technique in soybean seeds are promising, but their commercial application depends on getting more detailed information about the biochemical modifications caused by the treatment.

Therefore, this study was carried out to assess the biochemical changes associated with osmotic conditioning in seeds of different soybean varieties immediately after treatment and after storage for different periods of time.

\section{MATERIAL AND METHODS}

The study was carried out in the Laboratory for Physicchemical Analyses in the Nucleus for Biotechnology applied to Agriculture (BIOAGRO) at Universidade Federal de Viçosa (UFV). Soybean seeds of UFV 10, IAC 8 and Doko RC cultivars were multiplied in an experimental area, belonging to UFV, in 1994/95 agricultural season. Seed samples of the three cultivars were manually collected at the maturity stage $\mathrm{R} 8$ (95\% ripe pods). The seeds were then threshed in a stationary thresher and dried by natural conditions, until moisture content of $10-11 \%$. The seeds were sieved to separate impurities, placed in cotton bags and kept in a cold dry chamber $\left(10^{\circ} \mathrm{C}\right.$ and $70 \%$ relative humidity) until the end of the harvest and the beginning of the treatments.

Seeds from the three soybean cultivars underwent the drying back-process. The seeds were osmotically conditioned, using the methodology developed by Heydecker et al. (1973) and modified by Del Giúdice (1996). The samples were placed in gerbox type plastic boxes containing four sheets of blotting paper (germitest), moistened with $30 \mathrm{~mL}$ of PEG 6000 solution $+0.2 \%$ thiram fungicide, with osmotic potential adjusted to $-0.8 \mathrm{MPa}$ (Michel \& Kaufmann, 1973). The gerboxes with the osmotically conditioned seeds were taken to a B.O.D. type incubator, regulated to maintain a constant temperature of $20^{\circ} \mathrm{C}$, for a period of four days.

After the conditioning period, the seeds were washed in running water and dried back in an incubator with forced air circulation, for 48 hours at a temperature of $25^{\circ} \mathrm{C}$, to return to the initial moisture content (between 10 and $11 \%$ ). The dehydrated seeds were later stored in laboratory natural conditions, for periods of zero, three and six months. After each storage period the seeds were evaluated for protein, lipid, hexanal and fatty acid content.

The results were compared with two controls, nontreated seeds (dry seeds) and seeds imbibed in demineralized water for a time interval to allow a final degree of moisture similar to that obtained by the seeds in the solution containing the osmotic agent (PEG 6000). The moistening time of the seeds in demineralized water (control) varied depending on the variety used, and was determined by calibration curves, using imbibition intervals of zero, one, three and six hours. The results obtained for the UFV 10, IAC 8 and Doko RC cultivars were 5.23, 5.43 and 5.89 hours of imbibition, respectively. 
The protein content was determined using the total nitrogen (Kjeldahl's method), according to the Association of Official Analytical Chemists (1975) recommendation, with modifications. Three replications of $0.3 \mathrm{~g}$ from seed samples previous ground in a Willey type grinder and placed on grease proof paper were analyzed. The digestion phase was carried out in open tubes, using a digestor solution (concentrated sulfuric acid, copper sulphate and powdered selenium), which was heated slowly to a temperature of $350^{\circ} \mathrm{C}$. After obtaining the digested material, hydrogen peroxide at $30 \%$ was added, and the mixture heated for further 30 minutes. The liberated ammonia was collected in boric acid solution at $4 \%$ after reacting with sodium hydroxide $(40 \%)$ at the distillation phase. Titulation was carried out in a standard chlorine acid solution $0.05 \mathrm{~N}$. About $99.7 \%$ of the nitrogen was recuperated with this procedure. A factor of 6.25 was used for the conversion of nitrogen to protein.

Lipids were determined in a Soxhlet extractor device, using petroleum ether as a solvent, following the procedure described in the analytic rules of the Instituto Adolfo Lutz (1985), with 10 refluxes. Three replications of $5 \mathrm{~g}$ were assessed from previously ground seed samples for each treatment. The results, found by weight difference, were expressed in extracted oil percentage.

The soybean seeds hexanal content was determined using three replications of $0.5 \mathrm{~g}$. The seed samples submitted to treatments were ground in a Willey type grinder, placed in glass flasks with a rubber lid and stored in a freezer at $-20^{\circ} \mathrm{C}$. Hexanal analysis was carried out using gas chromatography by the head space technique. Shortly after the samples were removed from the freezer, $2 \mathrm{~mL}$ of $0.05 \mathrm{M}$ at $\mathrm{pH} 7.0$ sodium phosphate buffer were added to each flask, which was then sealed and put in a water bath for 20 minutes, at a temperature of $30^{\circ} \mathrm{C}$. The samples were then taken to the Shimadzu chromatograph, model GC-14B, equipped with head space, model HSS-2B and C-R7A integrator, for 15 minutes at $45^{\circ} \mathrm{C}$ and then, $0.8 \mathrm{~mL}$ of the liberated gases were injected. The results expressed in $\mathrm{mV}$ were transformed in $\mathrm{mg} \mathrm{g}^{-1}$ by calibration curve, using the following hexanal concentrations: $0.0,0.5,1.0,2.5,5.0$ and $10.0 \mathrm{mg} \mathrm{g}^{-1}$.

A Carbowax column, 25 meters long with an internal diameter of $0.53 \mathrm{~mm}$, was used in the hexanal analysis. The analysis conditions were: $45^{\circ} \mathrm{C}$ initial column temperature, which rose steadily to reach $200^{\circ} \mathrm{C}$; injector temperature, $200^{\circ} \mathrm{C}$ and flame ionizer detector temperature $250^{\circ} \mathrm{C}$.

The fatty acids present in the oil extracted from the soybean seeds, submitted to several treatments, were analyzed by gas chromatography, according to the methodology described by Bubeck et al. (1989). The oil was extracted in a Soxhlet extractor apparatus, using petroleum ether as a solvent. Fifteen $\mathrm{mL}$ of oil were collected per sample, and put in glass tubes. A quantity of $0.4 \mathrm{~mL}$ of sodium metoxide $1 \mathrm{M}$ were added to each sample, and left to react in a water bath at $30^{\circ} \mathrm{C}$ for approximately one hour to allow transesterification reaction in the fatty acids. Then $1 \mathrm{~mL}$ of distilled water plus $1 \mathrm{~mL}$ of hexane were added and the solution left to react for a period of one hour to collect the supernatant. After collecting the methyl ester-hexane mixture, another $1 \mathrm{~mL}$ of hexane (dilution) was added, and the sample was ready for analysis. The determination of the fatty acids was carried out in a Shimadzu chromatograph, model GC-17A, equipped with a C-R7A integrator, by injecting $1 \mathrm{~mL}$ of the sample. The results were expressed in percentages of the fatty acids present in each sample. The analysis conditions were: column, injector and flame ionization detector temperatures $240^{\circ} \mathrm{C}, 240^{\circ} \mathrm{C}$ and $280^{\circ} \mathrm{C}$, respectively.

A randomized complete block design was used, with treatments in a $3 \times 3 \times 3$ factorial scheme (cultivars $\mathrm{x}$ imbibition treatments $\mathrm{x}$ storage periods). The results underwent variance and regression analysis.

\section{RESULTS AND DISCUSSION}

Fig. 1 shows the protein content data of seeds of three soybean cultivars submitted to different drying back treatments, according to their storage periods. A sharp variability, dependent on the treatments, was found for the initial seed protein content of the different soybean cultivars. Generally, the seeds treated with PEG 6000 solution had the greatest initial protein values compared with the two controls (dry seeds and water imbibed seeds). Furthermore, these higher values in the protein content in seeds submitted to osmotic conditioning, followed by dehydration, remained greater than the other treatments during the three and six month storage periods under environmental conditions.

Several authors (Fu et al., 1988; Bray et al., 1989; Smith \& Coob, 1992) have shown that osmotic conditioning in seeds from some oil species has caused significant increases in the soluble protein content, compared with non-treated seeds from these same species. They further found that the increase in protein synthesis could be related to greater germination capacity and performance under field 

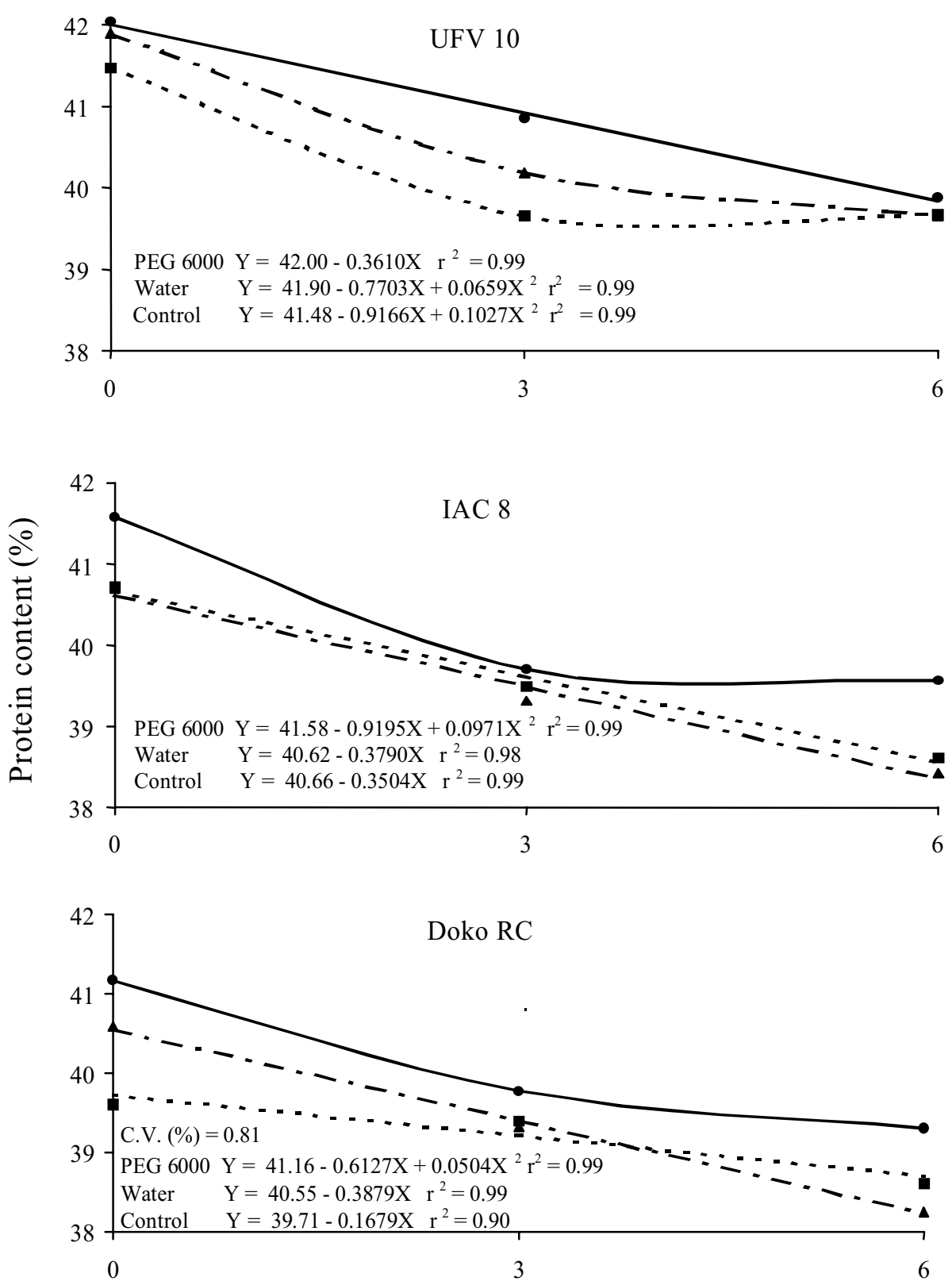

Storage periods (months)

—PEG 6000 - - Water - - - Control

FIG. 1. Protein content in seeds of three soybean cultivars submitted to imbibition in PEG 6000 solution (osmoconditioning), or in water, followed by dehydration, and control without imbibition treatment, in relation to the storage periods. 
conditions shown by the osmoconditioned seeds. Khan (1992) found that twice amino acids were incorporated in proteins during the first 24 hours of imbibition of sweet pepper seeds in PEG solutions (osmotic conditioning), compared with seeds soaked in water.

Generally, seed storage caused a decrease in the protein content for all the treatments. The lowest protein values were found in the six-month storage period. The pattern of reduction for this characteristic may be related to oxidation of the amino acids, due the increase in the respiratory activity and advance in the deterioration process of the stored seeds. Thus, prolonged seed storage would increase the metabolic activity of the seeds and consequently decrease the reserve substance content and reduce the dry material weight of the seeds (Bewley \& Black, 1994).

The analysis in Fig. 2 indicates the presence of variability among the soybean cultivars for lipid content present in the seeds. The cultivars UFV 10 and Doko RC had higher lipid contents than cultivar IAC 8.

Similarly to the protein content, the lipid content in the seeds decreased with storage time in all the treatments. This result may be explained by lipid oxidation in the seeds caused by the intensification of the deterioration process, as soybean seeds are known to be problematic in terms of conservation and storage, especially when temperatures and relative air humidity are not adequate. Soybean seeds quickly lose their physiological quality under these conditions, according to Priestley \& Leopold (1983).

The lipid content by osmotic conditioning was significantly higher than those of the two controls, at least up to the three month storage period (Fig. 2). At six months, only the IAC 8 cultivar had significantly higher lipid content in the osmotic conditioned seeds. Saha et al. (1990) found that the drying back treatment of soybean seeds had a beneficial effect, increasing the seed vigor and viability, suggesting that the treatment may be at least partly involved in causing a greater integration of the membrane system, by reducing peroxidation reaction in the lipids.

According to Wilson Junior \& McDonald Junior (1986) the deterioration process would have as consequence, the destructuring of the membrane systems at a cellular level with the lipid oxidation being the direct cause of the seed deterioration during storage. Furthermore, within the lipid fraction, the polyunsaturated fatty acids such as linoleic and linolenic are the most important and susceptible to oxidative degradation by enzymatic and nonenzymatic reactions. Jeng \& Sung (1994) observed that the increase in the peroxidation of lipids and the accumulation of hydroperoxides were observed in embryonic axis and cotyledon of aged peanut seeds.

The deterioration process has been associated with the loss of integrity of the endomembrane system and with cellular solution leakage because of the lipid oxidation process, including the phospholipides in the plasmatic membrane. Powell \& Matthews (1979) showed that a reduction in the phospholipid content of the membranes, especially of phosphatidilocoline, was a prime event during pea seed aging.

The treatment of seed hydration in water, followed by drying, showed a fairly sharp reduction in the lipid content in the seeds during storage (Fig. 2). This may be related to the deterioration process caused by the rapid imbibition because seeds from some leguminous plants, such as soybean, are especially susceptible to damage caused by rapid water absorption, which leads to an accentuated oxidation of the reserve lipids (Saha et al., 1990; Jeng \& Sung, 1994).

The results of hexanal aldehyde accumulation in the seeds of three soybean cultivars submitted to different imbibition treatments and storage periods are shown (Fig. 3). Weather conditions during storage caused greater hexanal production, which may be related to the reduction in the physiological quality of the seeds because of the greater deterioration (Braccini et al., 1997). The correlation between the accumulation of specific aldehydes, especially hexanal, during germination as an index of the rate of lipid peroxidation and the loss of vigor in soybean seeds has been discussed in a series of recent studies (Castro et al., 1988; Reis et al., 1989; Vidas et al., 1992). Furthermore, absence of lipoxigenase in the seeds has been investigated as an important mechanism for the reduction of aldehyde production (Queiroz, 1993; Nishiba et al., 1995). 

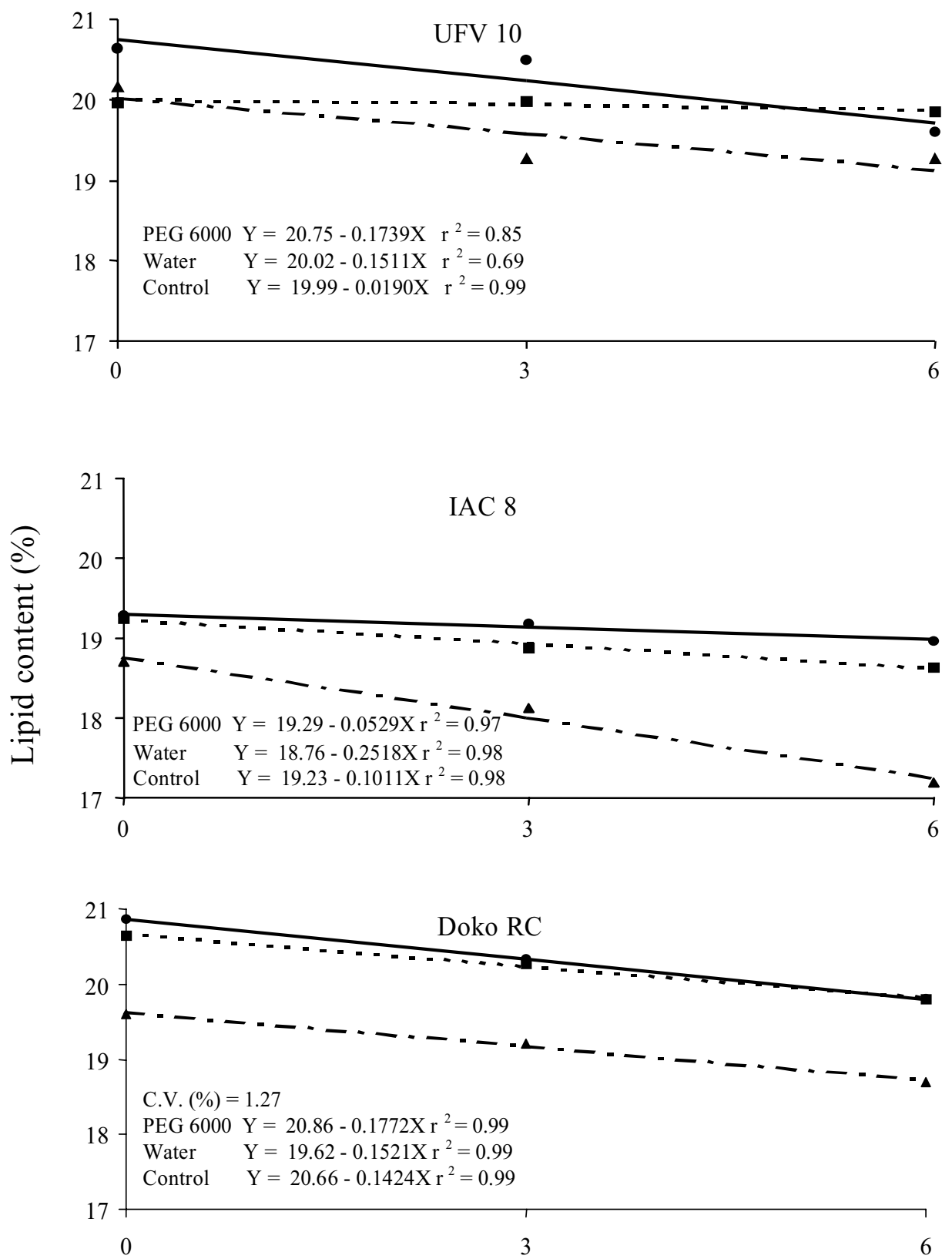

Storage periods (months)

— PEG 6000 _ - Water . . . Control

FIG. 2. Lipid content in seeds of three soybean cultivars submitted to imbibition in PEG 6000 solution (osmoconditioning), or in water, followed by dehydration, and control without imbibition treatment, in relation to the storage periods. 

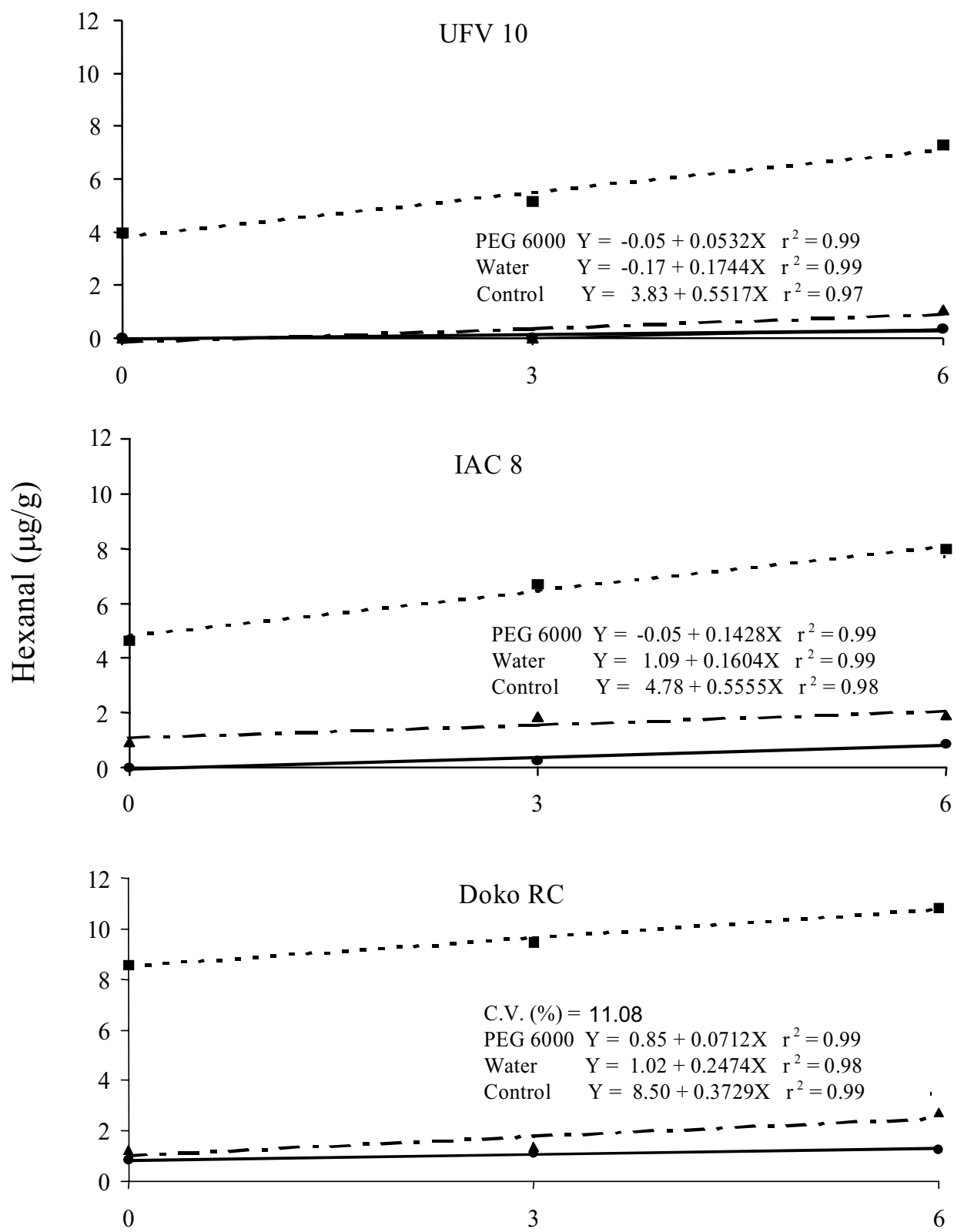

Storage periods (months)

— PEG $6000 \quad$ - - - Water _. - . Control

FIG. 3. Hexanal accumulation in seeds of three soybean cultivars submitted to imbibition in PEG 6000 solution (osmoconditioning), or in water, followed by dehydration, and control without imbibition treatment, in relation to the storage periods. 
Free radicals and hydroperoxides are relatively unstable products and have great potential of causing damage to the cell components, mainly the plasmatic membrane. The more stable chemical compounds, resulting from the degradation of these hydroperoxides, are responsible for later detrimental effects. The aldehydes formed in hydroperoxide degradation produce a series of cytotoxic effects. These aldehydes react with suphidrile groups, causing protein inactivation, reducing mitoses incidence in cells, inhibiting protein and DNA synthesis, among other effects, resulting in the loss of soybean seed quality (Wilson Junior \& McDonald Junior, 1986).

However, it was possible to find that seed soaking, either in PEG 6000 or in water (Fig. 3) presented a reduction in the hexanal values comparatively to untreated checks without soaking (dry seeds). The dry seeds of the three soybean cultivars accumulated hexanal during storage.

According to Hildebrand et al. (1990), experiments carried out with enzyme purification confirmed that lipoxigenase 3 might reduce the production of hexanal. Preliminary results suggest that lipoxigenase 3 reduce hexanal formation, converting the lipoxigenase product (13-hydroperoxide of unsaturated fatty acid) in forms unavailable for conversion to hexanal. Takamura et al. (1991) suggested that the isozyme lipoxigenase 3 is not capable of producing the hexanal precursor, inhibiting its formation by other metabolic routes.

Great variability was found among the soybean cultivars for hexanal production (Fig. 3). Doko RC cultivar had the greatest values of this aldehyde in all the seed storage periods. IAC 8 cultivar had intermediate values, whereas the lowest hexanal evolution was observed in UFV 10. Similar results were obtained by Vidas et al. (1992).

Comparing the dry back treatment in PEG 6000 solution with soaking in water under the same conditions (Fig. 3), it was possible to observe that the relative production of hexanal aldehyde was approximately 3.5 times greater for the water soaked check in cultivar UFV 10, after both three and six months of seed storage. For the cultivar IAC 8 , the increases caused by soaking the seeds in demineralized water were 4.2 and 2.6 times, respectively for the periods of three and six month storage. Finally, soaking cultivar Doko RC seeds in water increased the hexanal production by 1.7 and 2.0 times for the periods of three and six months, compared with the seeds soaked in PEG 6000. It was thus possible to conclude that seed storage increased hexanal production, however hexanal levels were smaller with seeds imbibition in PEG 6000 solution and in water, and that this lower accumulation resulting from the priming treatment may be related to the increase in germination and vigor shown by the osmoconditioned seeds of this species comparatively to untreated seeds (Braccini et al., 1997).

The Figs. 4 and 5 show the relative proportion of palmitic and stearic saturated fatty acids present in the soybean seeds. It was not possible to find a defined pattern for these characteristics because of the hydration treatments applied. Generally, an increase in the relative percentage of these fatty acids was observed during the soybean seed storage for the three cultivars under study, but there were some exceptions, depending on the soaking treatment used. A tendency to increase the relative proportion of oleic fatty acid along with the increase of seed storage periods was also observed (Fig. 6), except to Doko RC cultivar. This may be explained by the fact that as values of polyunsaturated fatty acids (linoleic and linolenic) decrease due to the lipid oxidation process, there will be an increase in the relative proportion of saturated fatty acids (Bubeck et al., 1989; Hildebrand, 1992).

The relative values of the linoleic acid percentage in soybean seeds during the storage periods are presented in Fig. 7. No significant differences were detected among the cultivars and soaking treatments for this characteristic. However, analysis of the results showed that the percentage of linoleic acid tended to decrease with the increase in storage time, which may be related with the lipid oxidation process in the seeds, according to Priestley \& Leopold (1983).

Oxidation of the lipid present in the cell membranes and the concomitant increase in the concentration of free fatty acids has been proposed as the main seed deterioration mechanism. The oxidative attack generally begins on the polyunsaturated fatty acids (linoleic and linolenic) found in the plasmatic 

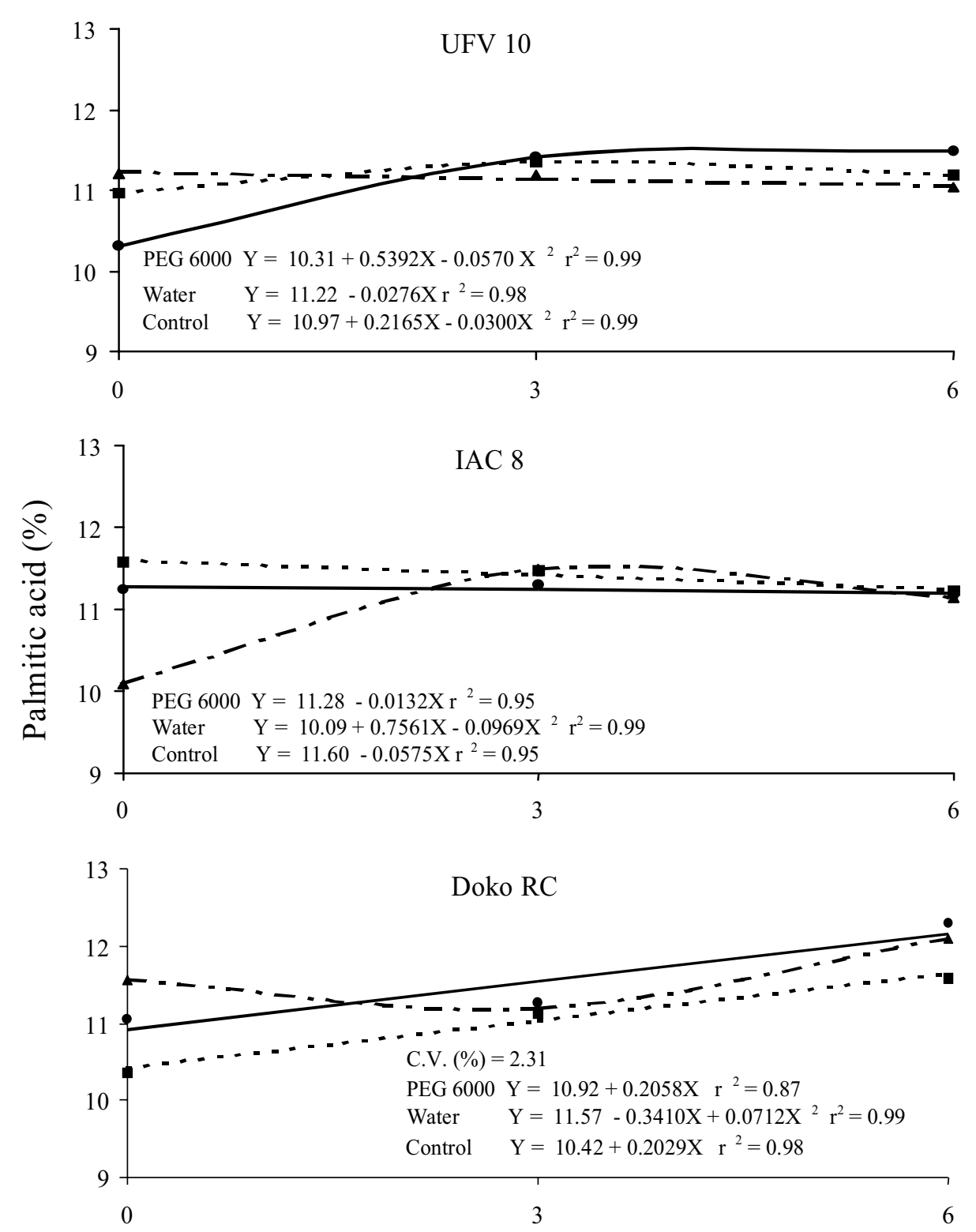

Storage periods (months)

_ PEG $6000 \quad-$ - Water - - - Control

FIG. 4. Palmitic fatty acid relative ratio in seeds of three soybean cultivars submitted to imbibition in PEG 6000 solution (osmoconditioning), or in water, followed by dehydration, and control without imbibition treatment, in relation to the storage periods. 

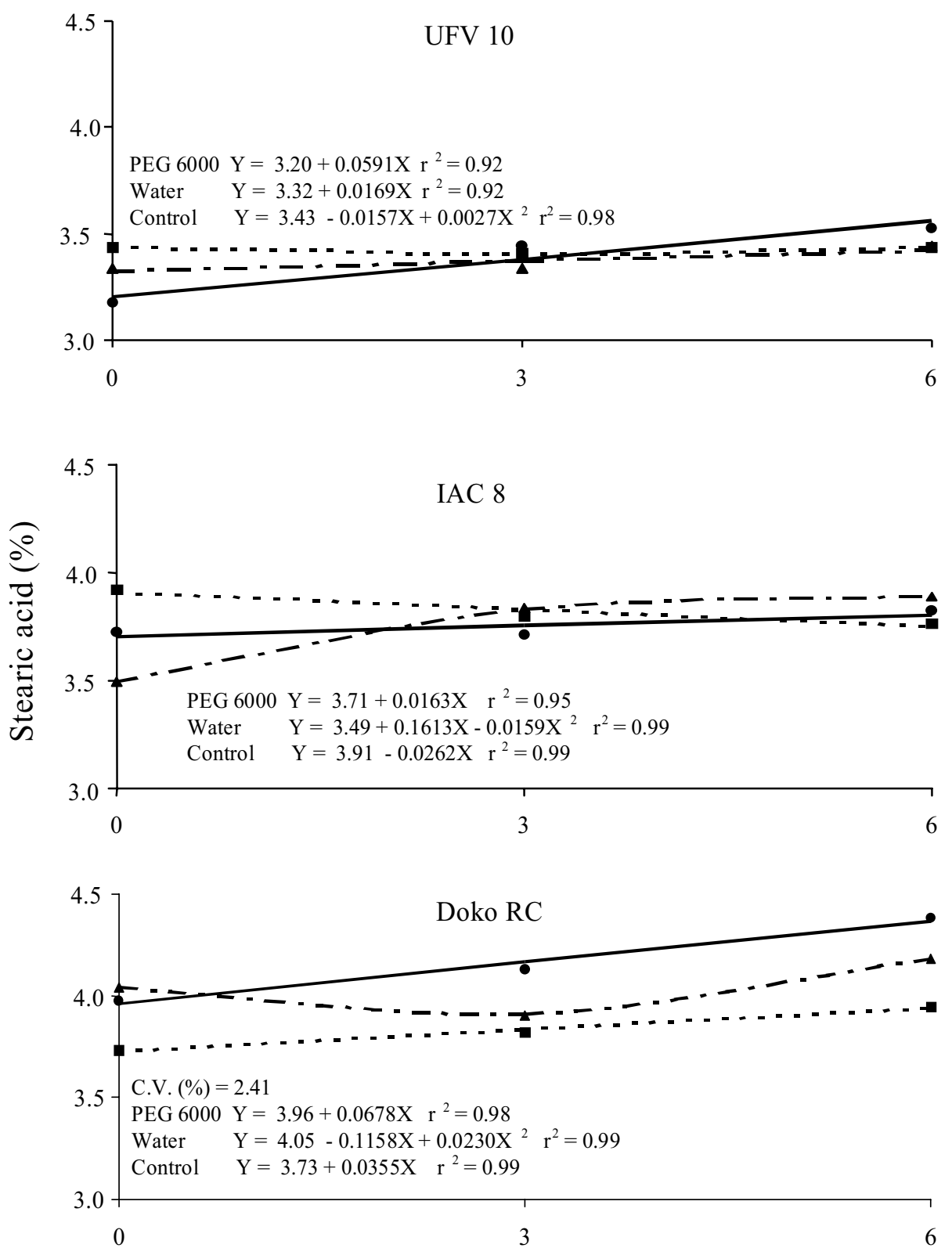

Storage periods (months)

_PEG 6000 - - - Water - . - Control

FIG. 5. Stearic fatty acid relative ratio in seeds of three soybean cultivars submitted to imbibition in PEG 6000 solution (osmoconditioning), or in water, followed by dehydration, and control without imbibition treatment, in relation to the storage periods. 

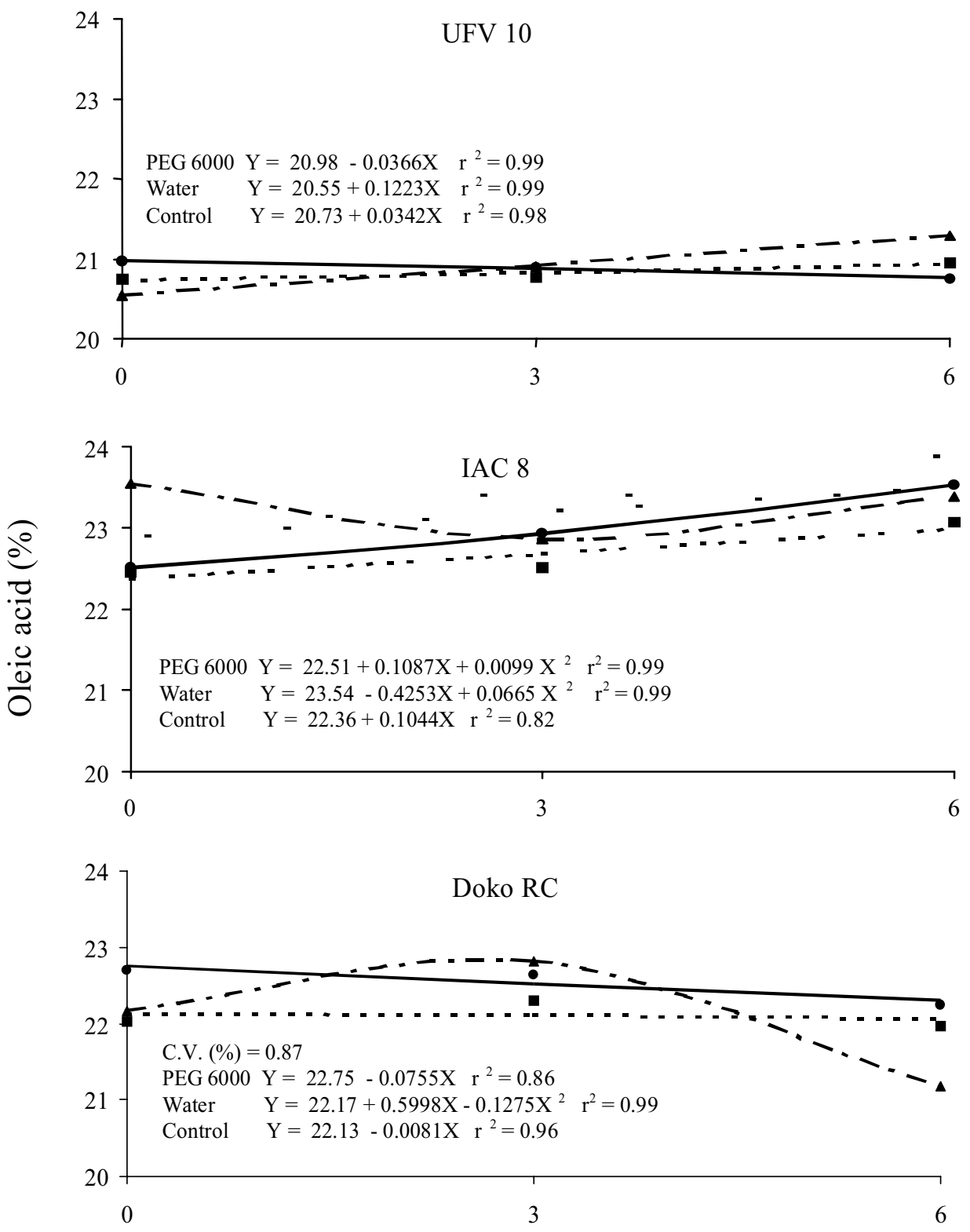

Storage periods (months)

_ PEG $6000 \quad$ - - Water _. . - Control

FIG. 6. Oleic fatty acid relative ratio in seeds of three soybean cultivars submitted to imbibition in PEG 6000 solution (osmoconditioning), or in water, followed by dehydration, and control without imbibition treatment, in relation to the storage periods. 
membrane. Thus, the first step in seed deterioration would be the loss of the membrane integrity, leading to an increase in its permeability and causing leakage of cellular solution during seed soaking (Wilson Junior \& McDonald Junior, 1986).

The speed of the oxidation reaction depends on the degree of insaturation present in the fatty acid molecule. Therefore, the greater the degree of insaturation present in the oil, the greater its susceptibility to oxidation. The first products formed from this reaction are the hydroperoxides (Hildebrand, 1992). In the presence of oxygen, the hydrocarbon chains of the fatty acids oxidize spontaneously, producing intermediate and highly reactive free radicals and a great variety of other secondary products resulting from the degradation of the hydroperoxides, such as aldehydes, acids, alcohols and cetones (Wilson Junior \& McDonald Junior, 1986). Generally the speed of these fatty acid oxidation reactions is highly accelerated by the presence of the lipoxigenase isozymes, which is found in the seeds of many cultivated species, especially soybean.

The linolenic fatty acid percentage varied (Fig. 8) significantly among cultivars and storage periods of soybean seeds (significant interaction). The IAC 8 cultivar was significantly different from UFV 10 and Doko RC in linolenic fatty acid content in the seeds. However, similarly to the results obtained for the proportion of linoleic acid (Fig. 7), a reduction in the linolenic acid content was again found with the increase of seed storage time.

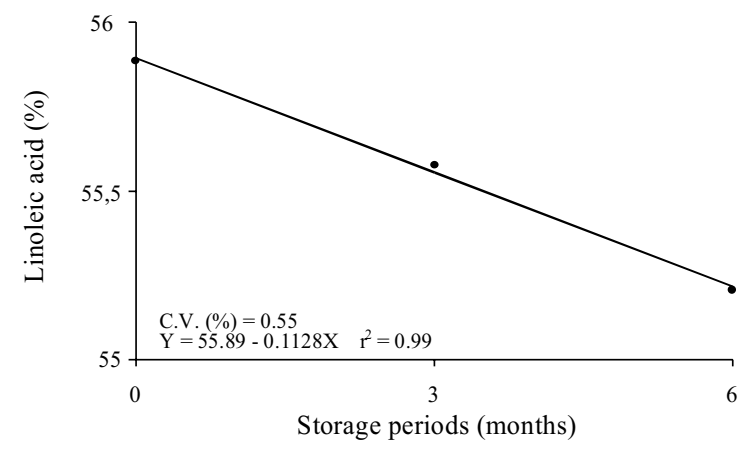

FIG. 7. Linoleic fatty acid relative ratio of soybean seeds, in relation to the storage periods.

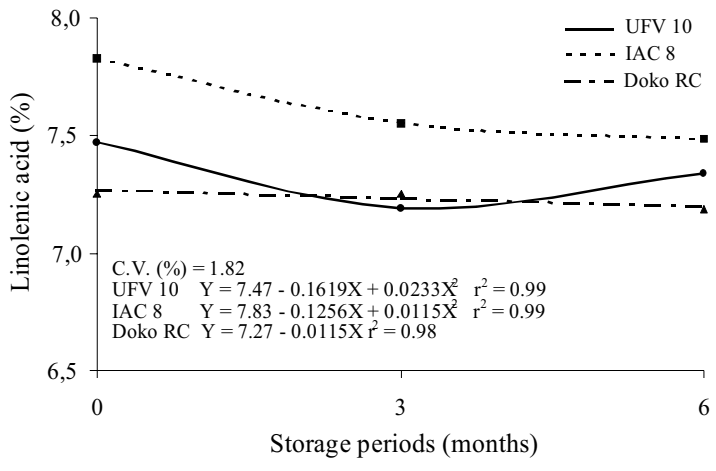

FIG. 8. Linolenic fatty acid relative ratio in seeds of three soybean cultivars, in relation to the storage periods.

Priestley \& Leopold (1983) found out that the storage for 44 months under natural conditions caused a sharp decline in the soybean seeds vigor and viability, which was associated with a decrease in the proportion of polyunsaturated fatty acids. Hildebrand (1992) concluded that the lipid peroxidation process leads to a reduction in the unsaturated fatty acid content in seeds.

\section{CONCLUSIONS}

1. Seed storage under laboratory natural conditions causes reduction in protein, lipid and polyunsaturated fatty acids content and promotes hexanal production for all treatments.

2. Storage periods reduce protein levels for all treatments, however the PEG 6000 treatment shows lower protein reduction.

3. The soybean seed storage increases hexanal production, but hexanal levels are smaller with osmoconditioning comparing to the other imbibition treatments.

\section{REFERENCES}

ASSOCIATION OF OFFICIAL ANALYTICAL CHEMISTS. Official methods of analysis. Washington, DC, 1975. 1054p.

BEWLEY, J.D.; BLACK, M. Seeds: physiology of development and germination. New York : Plenum, 1994. $445 \mathrm{p}$.

Pesq. agropec. bras., Brasília, v.35, n.2, p.433-447, fev. 2000 
BRACCINI, A.L.; REIS, M.S.; SEDIYAMA, C.S.; ROCHA, V.S.; SEDIYAMA, T. Influência do processo de hidratação-desidratação na capacidade germinativa de sementes de soja submetidas ao armazenamento. Revista Brasileira de Sementes, Brasília, v.19, n.1, p.80-87, 1997.

BRADFORD, K.J. Manipulation of seed water relations via osmotic priming to improve germination under stress conditions. HortScience, Alexandria, v.21, n.5, p.1105-1112, 1986.

BRAY, C.M.; DAVISON, P.A.; ASHRAF, M.; TAYLOR, R.M. Biochemical changes during osmotic priming of leek seeds. Annals of Botany, London, v.63, p.185-193, 1989.

BUBECK, D.M.; FEHR, W.R.; HAMMOND, E.G. Inheritance of palmitic and stearic acid mutants of soybean. Crop Science, Madison, v.29, p.652-656, 1989.

CASTRO, C.A.S.; SEDIYAMA, C.S.; MOREIRA, M.A.; SILVA, R.F.; REZENDE, S.T.; SEDIYAMA, T.; ROCHA, V.S. Liberação do aldeído n-hexanal como índice para estimar o vigor de sementes de soja. Revista Ceres, Viçosa, v.35, n.202, p.569-577, 1988.

DEL GIÚDICE, M.P. Condicionamento osmótico de sementes de soja (Glycine max (L.) Merrill). Viçosa, MG : UFV, 1996. 130p. Tese de Doutorado.

DELL'AQUILA, A.; TRITTO, V. Germination and biochemical activities in wheat seeds following delayed harvesting, ageing and osmotic priming. Seed Science and Technology, Zürich, v.19, p.73-82, 1991.

FU, J.R.; LU, X.H.; CHEN, R.Z.; ZHANG, B.Z.; LIU, Z.S.; LI, Z.S.; CAI, D.Y. Osmoconditioning of peanut (Arachis hypogea L.) seeds with PEG to improve vigour and some biochemical activities. Seed Science and Technology, Zürich, v.16, p.197-212, 1988.

HEYDECKER, W.; HIGGINS, J.; GULLIVER, R.L. Accelerated germination by osmotic seed treatment. Nature, London, v.246, n.5427, p.42-44, 1973.

HEYDECKER, W.; HIGGINS, J.; TURNER, Y.J. Invigoration of seeds? Seed Science and Technology, Zürich, v.3, n.3/4, p.881-888, 1975.

HILDEBRAND, D.F. Altering fatty acid metabolism in plants. Food Technology, Chicago, v.1, n.1, p.7174, 1992.
HILDEBRAND, D.F.; HAMILTON-KEMP, T.R.; LOUGHRIN, J.H.; ALI, K.; ANDERSEN, R.A. Lipoxygenase 3 reduces hexanal production from soybean seed homogenates. Journal of Agricultural and Food Chemistry, Washington, DC, v.38, p.1934-1936, 1990.

INSTITUTO ADOLFO LUTZ. Normas analíticas do Instituto Adolfo Lutz: métodos químicos e físicos para análise de alimentos. São Paulo, 1985. v.1, 533p.

JENG, T.L.; SUNG, J.M. Hydration effect on lipid peroxidation and peroxide-scavenging enzymes activity of artificially aged peanut seed. Seed Science and Technology, Zürich, v.22, p.531-539, 1994.

KHAN, A.A. Preplant physiological seed conditioning. Horticultural Review, Edinburgh, v.13, p.131-181, 1992.

KNYPL, J.S.; KHAN, A.A. Osmoconditioning of soybean seeds to improve performance at suboptimal temperatures. Agronomy Journal, Madison, v.73, p.112-116, 1981.

KRZYZANOWSKI, F.C.; GILIOLI, J.L.; MIRANDA, L.C. Produção de sementes nos Cerrados. In: ARANTES, N.E.; SOUZA, P.I. de M. de (Eds.). Cultura da soja nos cerrados. Piracicaba : POTAFOS, 1993. p.465-522.

LANTIERI, S.; SARACCO, F.; KRAAK, H.L.; BINO, R.J. The effects of priming on nuclear replication activity and germination of pepper (Capsicum annuum) and tomato (Lycopersicon esculentum) seeds. Seed Science Research, Wallingford, v.4, p.81-87, 1994

MICHEL, B.E.; KAUFMANN, M.R. The osmotic potential of polyethylene glycol 6000. Plant Physiology, Lancaster, v.51, n.6, p.914-916, 1973.

NISHIBA, Y.; FURUTA, S.; HAJIKA, M.; IGITA, K.; SUDA, I. Hexanal accumulation and DETBA value in homogenate of soybean seeds lacking two or three lipoxygenase isozymes. Journal of Agricultural and Food Chemistry, Washington, DC, v.43, p.738$741,1995$.

POWELL, A.A.; MATTHEWS, S. The influence of testa condition on the imbibition and vigour of pea seeds. Journal of Experimental Botany, Oxford, v.30, p.193-197, 1979. 
PRIESTLEY, D.A.; LEOPOLD, A.C. Lipid changes during natural aging of soybean seeds. Physiologia Plantarum, Copenhagen, v.59, p.467-470, 1983.

QUEIROZ, L.R. Produção de aldeídos na germinação e qualidade fisiológica de sementes de genótipos de soja com ausência de lipoxigenases. Viçosa, MG : UFV, 1993. 52p. Tese de Mestrado.

REIS, W.J.P.; ROCHA, V.S.; REZENDE, S.T.; MOREIRA, M.A.; SEDIYAMA, C.S. Correlação entre a evolução de n-hexanal e aldeídos totais e a germinação e vigor de sementes de soja. Revista Ceres, Viçosa, v.36, n.203, p.27-37, 1989.

SAHA, R.; MANDAL, A.K.; BASU, R.N. Physiology of seed invigoration treatments in soybean (Glycine $\max$ L.). Seed Science and Technology, Zürich, v.18, p.269-276, 1990.

SMITH, P.T.; COOB, B.G. Physiological and enzymatic characteristics of primed, redried, and germinated pepper seeds (Capsicum annuum L.). Seed Science and Technology, Zürich, v.20, p.503-513, 1992.
SUNG, F.J.M.; CHANG, Y.H. Biochemical activities associated with priming of sweet corn seeds to improve vigor. Seed Science and Technology, Zürich, v.21, p.97-105, 1993.

TAKAMURA, H.; KITAMURA, K.; KITO, M. Inhibition by lipoxygenase- 3 of $n$-hexanal generation in soybeans. FEBS Letters, Amsterdam, v.292, n.1/2, p.42-44, 1991.

VIDAS, R.M.R.; MOREIRA, M.A.; PINHEIRO, W.J.; ROCHA, V.S.; REZENDE, S.T.; SEDIYAMA, C.S. Relação entre vigor e alterações bioquímicas na germinação de sementes de soja. Revista Brasileira de Fisiologia Vegetal, Londrina, v.4, n.1, p.49-53, 1992

WILSON JUNIOR, D.O.; McDONALD JUNIOR, M.B. The lipid peroxidation model of seed ageing. Seed Science and Technology, Zürich, v.14, p.269-300, 1986. 